\title{
ASEAN Towards a Global Halal Logistics Through the Digitally Enabled Community
}

Sutan Emir Hidayat, Department of Islamic Economics, Gunadarma University \& National Committee for Islamic Economy and Finance (KNEKS), Indonesia

Khairunnisa Musari, Department of Islamic Economics, Kiai Haji Achmad Shiddiq State Islamic University (UIN KHAS), Jember, Indonesia

iD https://orcid.org/0000-0003-0525-9903

\section{ABSTRACT}

The Association of Southeast Asian Nations (ASEAN) is leading the development of global halal trade and has the opportunity to become a leader in the global halal supply chain, especially in global halal logistics. Given the push towards digital transformation in creating a halal ecosystem and regarding the agenda of ASEAN towards a digitally enabled economy, this study wants to examine whether ASEAN digitally enabled community is correlated with ASEAN's chances of becoming a global halal logistics. Through a correlation test, it is found that there is a statistically significant relationship between ASEAN digitally enabled community, as measured in internet subscribers/ users per 100 persons and cellular/mobile phone per 100 persons, and the opportunity for ASEAN to become a global halal logistics, measured in ASEAN GDP, total air cargo, total trade in goods, and international air passenger traffic. This is probably the first study that preliminarily confirms digitally enabled community is very important to strengthen ASEAN's opportunities to become the global halal logistics leader.

\section{KEYWORDS}

ASEAN, Digital Economy, Digitally Enabled Community, Halal Ecosystem, Halal Industry, Halal Logistics, Halal Supply Chain

\section{INTRODUCTION}

The Association of Southeast Asian Nations (ASEAN) region is one of the fastest growing economies in the world. In August 2020, ASEAN Secretariat notes its concatenated gross domestic product (GDP) of US \$3.166 million in 2019 grew by $28.2 \%$ from 2015 figure that stood at US \$2.469 million. Nowadays, this communion is the seventh-largest economy in the world and is projected to become the fourth-largest by 2050. If Asia is home to 65\% of the world's Muslims, the ASEAN region is home to $25 \%$ of the world's Muslims and more than $42 \%$ of Southeast Asia's Muslims. Today, the number of population in ASEAN has reached more than 650 million people.

ASEAN is leading the development of global halal trade. Some ASEAN member states are known as leading countries in the world that drive the global halal industry. Malaysia, Indonesia, Singapore, and Thailand are the top 15 countries in the Global Islamic Economy Indicators (GIEI) in the last seven years. Referring to State of the Global Islamic Economy Report 2020/2021, the four 
countries are also top 10 countries in Halal Food and Halal Media \& Recreation sectors. Malaysia, Thailand, Indonesia, Singapore are the top 10 countries in Muslim Friendly-Travel/Halal Travel. Malaysia and Indonesia are the top 10 countries in Islamic Finance, Halal Modest Fashion, and Halal Pharmaceutical \& Cosmetics sectors (DinardStandard, 2020).

Based on its leadership in global halal trade, ASEAN also has the opportunity to become a leader in the halal supply chain, especially in halal logistics. Given the push towards digital transformation in creating a halal ecosystem, this study wants to examine whether ASEAN digitally-enabled community is correlated with ASEAN's chances of becoming a global halal logistics or not. The ASEAN digitally-enabled community in this study is represented by the number of internet users and cellular/mobile phone users. Meanwhile, the opportunity for ASEAN to become a global halal logistics is represented by the ASEAN GDP, ASEAN total air cargo, ASEAN total trade in goods, and ASEAN international air passenger traffic.

Tieman (2011, 2013), Tieman, van der Vorst, \& Ghazali (2012), Tieman \& Ghazali (2014), Talib, Hamid, \& Zulfakar (2015), Azzam \& Abdullah (2020), Abdullah \& Azzam (2020), Kadir (2020), Zaroni \& Musari (In Press) stated that the logistics in the halal industry plays an important role in the country's economic growth especially to fulfill halal products demand from both domestic and global markets. Halal industry which includes pharmaceutical, cosmetics, health care, finance, manufacturing, tourism, and food and beverage products, continues to show positive growth in both demand and value. Halal products and services are increasingly recognized globally as an indicator of a new level for safety and quality assurance.

Azzam \& Abdullah (2020) highlighted that the integrity of the entire halal supply chain is a very important component for the halal industry to maintain effective control of the halal supply chain which is more complex than traditional logistics operations. Certain Muslim markets around the world require different taste, packaging, distribution, and certification. Thus, adopting halal requirements in all aspects of the supply chain of this halal ecosystem becomes a necessity and offers new market opportunities. Therefore, countries around the world, including ASEAN, are emerging as market players competing with each other in the halal industry.

The main focus of this study is to describe the existence of ASEAN as a halal community and the commitment to developing the digital economy. This study will also describe an opportunity for ASEAN to become a global halal logistics as part of the global halal value chain. Regarding the agenda of ASEAN towards a digitally-enabled economy that is secure, sustainable, and transformative in order to enable an innovative, inclusive, and integrated ASEAN Community, this study will do a correlation test as a bivariate analysis that measures the strength of association and the direction of the relationship between ASEAN digitally-enabled community and chances of becoming a global halal logistics.

\section{ASEAN, A Halal Community}

Referring to State of the Global Islamic Economy Report, there are four ASEAN member states which are in Top 15 Countries in the Global Islamic Economy Indicators (GIEI) at least in the last seven years. They are Malaysia, Indonesia, Brunei, and Singapore. Malaysia has always been in the top ranking and has not been overtaken. In GIEI 2020, Indonesia ranks the fourth for the first time after previously stay in ranks the tenth, eleventh and just already in the GIEI 2019 ranks the fifth. However, there is also another ASEAN country namely Thailand which, although is not in the Top 15 Countries of GIEI, it is in the Top 10 Countries for Muslim Friendly-Travel sector.

Actually, attention to the halal industry is not only available in the above four ASEAN countries. Other ASEAN countries are also concerned about the halal industry, particularly for halal food. With a significant population of Muslims, ASEAN as a region has been aware of the urgency and importance of chasing collaboration on halal food. Therefore, in order to escalate collaboration and put ASEAN in a strategic position on global halal food, the ASEAN General Guidelines in the Preparation and 
Table 1. Top 15 Countries in the GIEI

\begin{tabular}{|c|c|c|c|c|c|c|c|}
\hline No. & 2014-2015 & 2015-2016 & 2016-2017 & 2017-2018 & 2018-2019 & 2019-2020 & $2020-2021$ \\
\hline 1 & Malaysia & Malaysia & Malaysia & Malaysia & Malaysia & Malaysia & Malaysia \\
\hline 2 & UAE & UAE & UAE & UAE & UAE & UAE & $\begin{array}{l}\text { Saudi } \\
\text { Arabia }\end{array}$ \\
\hline 3 & Bahrain & Bahrain & Bahrain & $\begin{array}{c}\text { Saudi } \\
\text { Arabia }\end{array}$ & Bahrain & Bahrain & UAE \\
\hline 4 & Oman & $\begin{array}{l}\text { Saudi } \\
\text { Arabia }\end{array}$ & $\begin{array}{l}\text { Saudi } \\
\text { Arabia }\end{array}$ & Bahrain & $\begin{array}{l}\text { Saudi } \\
\text { Arabia }\end{array}$ & $\begin{array}{l}\text { Saudi } \\
\text { Arabia }\end{array}$ & Indonesia \\
\hline 5 & $\begin{array}{l}\text { Saudi } \\
\text { Arabia }\end{array}$ & Pakistan & Oman & Oman & Oman & Indonesia & Jordan \\
\hline 6 & Qatar & Oman & Pakistan & Pakistan & Jordan & Oman & Bahrain \\
\hline 7 & Kuwait & Kuwait & Kuwait & Qatar & Qatar & Jordan & Kuwait \\
\hline 8 & Jordan & Qatar & Qatar & Kuwait & Pakistan & Pakistan & Pakistan \\
\hline 9 & Pakistan & Jordan & Jordan & Brunei & Kuwait & Kuwait & Iran \\
\hline 10 & Indonesia & Indonesia & Indonesia & Jordan & Indonesia & Qatar & Qatar \\
\hline 11 & Brunei & Singapore & Singapore & Indonesia & Brunei & Brunei & Oman \\
\hline 12 & Sudan & Sudan & Brunei & Iran & Sudan & Sudan & Turkey \\
\hline 13 & Singapore & Egypt & Sudan & Singapore & Iran & Turkey & Nigeria \\
\hline 14 & Turkey & Iran & Iran & Sudan & Bangladesh & Iran & Sri Lanka \\
\hline 15 & Australia & Bangladesh & Bangladesh & Bangladesh & Turkey & Bangladesh & Singapore \\
\hline
\end{tabular}

Source: State of the Global Islamic Economy Report 2014-2015, 2015-2016, 2016-2017, 2017-2018, 2018-2019, 2019-2020, Processed

Handling of Halal Food with ASEAN Halal Logo has been published as a primary requirement for intra-ASEAN trade in halal food.

In 2017, ASEAN member countries through the ASEAN Working Group on Halal Food (AWGHF) have done an agreement to develop a Plan of Action (POA) for the ASEAN Cooperation in Halal Food during 2017-2020 and continued to be applied in 2021-2025 period. Some strategic thrusts have been implemented including improving sustainability production, green technology, resource management system, and minimizing loss or waste before/post-harvest. Then, enhancing trade facilitation, economic integration, and market access, ensuring food security, food safety, better nutrition, and equitable distribution as well as assisting resource-constrained small producers and small medium enterprises (SMEs) to improve productivity, technology, and product quality, meet global market standards and increase competitiveness, then strengthening ASEAN joint approaches on international and regional issues.

Likewise, the programs that organized to implement the agreed-upon strategies, including: promoting contract farming practice for halal food production, conducting capacity development for small farmers and SMEs to improve adoption of ASEAN halal/food handling best practices such as training and workshop on halal slaughtering, halal meat processing, halal meat packaging, also developing ASEAN halal quality management systems, ASEAN guidelines for halal food and certification. Most ASEAN Member States have established halal institutions in their jurisdictions especially to issue halal certification and develop halal industry as shown in Table 2 below.

By reviewing the GIEI during seven years, the potential of halal sector of the four ASEAN member states is shown by Table 3. Malaysia is always at the top of top 4 countries in Halal Food, Islamic Finance, and Muslim-Friendly Travel/Halal Travel. Indonesia, Singapore, and Malaysia 
Table 2. List of The Halal Websites in ASEAN Member States

\begin{tabular}{|c|c|}
\hline ASEAN Member States & Halal Websites \\
\hline \multirow{3}{*}{ Malaysia } & http://www.halal.gov.my/v4 \\
\hline & https://www.halalverified.com \\
\hline & https://www.globalhalaldatapool.com \\
\hline Indonesia & http://www.halamui.org \\
\hline Singapore & https://www.muis.gov.sg/ \\
\hline Philippines & https://www.nmis.gov.ph \\
\hline \multirow{4}{*}{ Thailand } & http://www.halinst.psu.ac.th/th \\
\hline & https://www.halalscience.org/?lang=en \\
\hline & https://www.halalstandard.or.th \\
\hline & https://www.cicot.or.th/en \\
\hline Vietnam & https://halal.vn/en \\
\hline
\end{tabular}

Source: ASEAN Food Safety Network (AFSN)

become the leaders in Modest Fashion. Singapore and Malaysia lead in Halal Media \& Recreation and Halal Pharmaceuticals \& Cosmetics.

All the above explanation shows that ASEAN's leadership in global halal trade also brings opportunities to become a leader in the global halal supply chain, particularly in global halal logistics. Malaysia, Indonesia, Singapore, Brunei Darussalam, and Thailand are recognized as the world's foremost countries driving the global halal industry. That is why ASEAN also can be called a halal community. Moreover, ASEAN is home to $25 \%$ of the world's Muslims and more than $42 \%$ of Southeast Asian Muslims. The region is currently the seventh-largest economy in the world and is projected to be the fourth-largest by 2050 .

However, there are still some issues and challenges that need to be tackled in order to accelerate halal community in ASEAN. Zailani, Iranmanesh, Aziz, and Kanapathy (2017) identified several issues and challenges in Malaysia among them are non-standardized halal guidelines, non-existence of an internationally accepted halal certification body, absence of strong collaboration between governing authorities, and low level of awareness on halal logistics.

\section{ASEAN, a Digitally-Enabled Community}

In Bain \& Company Report, Hoppe, May \& Lin (2018) wrote the digitalization in the ASEAN member states which is still at the early stage of development at that time. Comparing the contribution of digital economy to gross domestic product (GDP) in ASEAN with other regions, the contribution is still relatively small. For example, digital economy contributed $16 \%$ of GDP in China and $35 \%$ in the US, While ASEAN's digital economy represented only 7\% of the GDP in the same year. However, the region has much to gain by laying the foundation for the digital economy to power and accelerate intraregional trade and growth through digital integration. Digital integration will be critical for ASEAN businesses to compete at home and overseas. It has the power to escalate small and medium enterprises (SMEs) into regional and global players. In 2025, digital integration is estimated to book US $\$ 1$ trillion volume of transaction within ASEAN's GDP.

According to USAID (2020), Southeast Asia has the potential to become one of the world's top five digital economies. Its digital market has expanded threefold in the past three years and represents 7\% of ASEAN's US\$2.8 trillion GDP. Kemp \& Moey (2019) highlighted hundreds of millions of people across Southeast Asia already shop online, and the value of e-commerce spent in the region 
Table 3. The Halal Sector Potency of Malaysia, Indonesia, Singapore, and Brunei

\begin{tabular}{|c|c|c|c|c|c|c|c|c|}
\hline Sector & $\begin{array}{c}\text { ASEAN Member } \\
\text { States }\end{array}$ & 2014 & 2015 & 2016 & 2017 & 2018 & 2019 & 2020 \\
\hline \multirow{4}{*}{ Halal Food } & Malaysia & 81.4 & 78 & 55 & 89 & 81 & 74.3 & 209.8 \\
\hline & Indonesia & 36.3 & 40 & 40 & 42 & 48 & 47 & 71.5 \\
\hline & Singapore & 46.0 & 40 & 39 & 51 & n.a & n.a & 125.2 \\
\hline & Brunei & 41.1 & n.a & 45 & 52 & 58 & 53 & n.a \\
\hline \multirow{4}{*}{ Islamic Finance } & Malaysia & 162.2 & 176 & 189 & 193 & 173 & 147.9 & 389.0 \\
\hline & Indonesia & 36.1 & 35 & 38 & 42 & 46 & 54 & 111.6 \\
\hline & Singapore & 12.0 & 21 & 22 & 21 & n.a & n.a & 16.9 \\
\hline & Brunei & 30.8 & $\mathrm{n} . \mathrm{a}$ & 27 & 41 & 43 & 35 & n.a \\
\hline \multirow{4}{*}{$\begin{array}{l}\text { Muslim-Friendly } \\
\text { Travel/Halal Travel }\end{array}$} & Malaysia & 101.4 & 86 & 70 & 109 & 92 & 95.5 & 98.3 \\
\hline & Indonesia & 35.5 & 34 & 35 & 46 & 65 & 52 & 45.3 \\
\hline & Singapore & 56.2 & 58 & 44 & 25 & n.a & n.a & 42.6 \\
\hline & Brunei & 29.0 & $\mathrm{n} . \mathrm{a}$ & 22 & 24 & 26 & 30 & n.a \\
\hline \multirow{4}{*}{ Modest Fashion } & Malaysia & 20.5 & 20 & 26 & 31 & 33 & 35.6 & 43.7 \\
\hline & Indonesia & 19.4 & 20 & 21 & 20 & 34 & 37.9 & 57.9 \\
\hline & Singapore & 24.5 & 27 & 26 & 33 & n.a & n.a & 30.6 \\
\hline & Brunei & 6.4 & n.a & 12 & 13 & 12 & 11 & n.a \\
\hline \multirow{4}{*}{$\begin{array}{c}\text { Halal } \\
\text { Pharmaceuticals \& } \\
\text { Cosmetics }\end{array}$} & Malaysia & 57.4 & 50 & 61 & 62 & 96 & 60.6 & 80.2 \\
\hline & Indonesia & 41.3 & 40 & 41 & 42 & 44 & 42 & 47.5 \\
\hline & Singapore & 53.0 & 56 & 56 & 63 & n.a & n.a & 62.9 \\
\hline & Brunei & 43.5 & n.a & 39 & 35 & 57 & 49 & n.a \\
\hline \multirow{4}{*}{$\begin{array}{l}\text { Halal Media \& } \\
\text { Recreation }\end{array}$} & Malaysia & 52.7 & 40 & 38 & 57 & 51 & 64 & 59.9 \\
\hline & Indonesia & 9.1 & 8 & 9 & 10 & 16 & 17 & 43.6 \\
\hline & Singapore & 90.7 & 88 & 75 & 79 & n.a & n.a & 46.8 \\
\hline & Brunei & 36.2 & n.a & 30 & 29 & 37 & 44 & n.a \\
\hline
\end{tabular}

Source: State of the Global Islamic Economy Report 2014-2015, 2015-2016, 2016-2017, 2017-2018, 2018-2019, 2019-2020, Processed

passed US\$50 billion in 2018, an annual increase of more than 20\%. The internet economy is already accounted for almost $3 \%$ of the region's GDP, and Google and Temasek project that this will rise to $8 \%$ of the GDP by 2025.

The ASEAN Post Team (2019) wrote Southeast Asia's internet economy has reached US\$100 billion for the first time and is expected to triple by 2025. Southeast Asia currently has 360 million internet users, an increase of 100 million from four years ago - paving the way for a $39 \%$ increase in the value of Southeast Asia's internet economy, from US\$72 billion in 2018 to US\$100 billion in 2019. Another key finding would be that the region's internet economy will be worth US $\$ 300$ billion by 2025 . Crucially, the 2016 and 2017 reports foresaw a US $\$ 200$ billion regional internet economy by 2025 while last year's projection was US $\$ 240$ billion thanks to "drastic market acceleration".

Further, OECD (2019) noted that Indonesia, Malaysia and Singapore are faring better in terms of co-location facilities and internet exchange points (IXPs) relative to other ASEAN countries while Myanmar, Lao PDR and the Philippines lag regional peers. IXPs and data centres are two important elements enabling efficient management of internet traffic. IXPs, where internet traffic is exchanged 
Table 4. Share of Internet Users and Contribution of ICT Sector in ASEAN's GDP

\begin{tabular}{|l|c|c|}
\hline & $\begin{array}{c}\text { Share of Population using the Internet (\%, } \\
\text { 2017) }\end{array}$ & ICT (2019) \\
\hline Malaysia & 80 & 32 \\
\hline Indonesia & 85 & \\
\hline Singapore & 95 & \\
\hline Brunei & 60 & \\
\hline Phillipines & 53 & \\
\hline Thailand & 50 & \\
\hline Vietnam & 34 & \\
\hline Cambodia & 31 & \\
\hline Myanmar & 26 & \\
\hline Lao PDR & $55.1(2018)$ & \\
\hline ASEAN's Population & & $3 \%$ \\
\hline $\begin{array}{l}\text { Contribution of ICT Sector in ASEAN's GDP } \\
\text { (US\$ Billions) }\end{array}$ & & \\
\hline ASEAN's GDP (\% of Total) & & \\
\hline $\begin{array}{l}\text { Employment in ICT Sector within ASEAN } \\
\text { (Millions) }\end{array}$ & & \\
\hline
\end{tabular}

Source: OECD (2019) and Bain \& Company Report in Hoppe, May \& Lin (2018)

between networks based on agreements between network operators, play a significant role in this internet ecosystem.

The ICT sector plays a key role in facilitating digitally-enabled trade in goods and services, which in turn fuels economic growth. Advancement in the ICT sector has made it possible to conduct domestic and cross-border trade at a faster pace than ever before. Hoppe, May \& Lin (2018) highlighted the ICT sector in ASEAN has grown 9\% annually in the past five years and now is contributing more than US $\$ 113$ billion in ASEAN GDP. In the 2017, United Nations ICT Index, which measures development in ICT across countries, ASEAN member states have all improved, especially with Myanmar and Laos, which moved up five spots from 2016. The following Table 4 shows share of population using the internet in 2017 and contribution of ICT sector in ASEAN's GDP by 2019.

Referring to a digital monitoring service, wearesocial.com, Aravindan (2019) from Reuters reported that there are 360 million internet users across the countries covered in the report - Indonesia, Malaysia, Vietnam, Singapore and the Philippines - up from 260 million in four years earlier. This is still far compared to around 4.4 billion internet users worldwide, up 9 percent from a year ago. By 2025, Clarivate Report (2020) also highlighted Southeast Asia is expected to grow to a US \$300 billion as millions of people in the region take up online shopping and embrace ride-share food delivery. More than US \$37 billion has been invested in Southeast Asian online companies over the past four years with the majority going into e-commerce firms. Facilitating this unprecedented rate of growth which changing consumer behavior, accordingly, affordable internet access, widespread smartphone usage, and trust in digital services are essential.

In the future, the ICT sector will continue to grow, supported by the existing infrastructure and the initiatives under the ASEAN ICT Masterplan 2020. Further, entrepreneurial SMEs will keep up the momentum, building on the infrastructure which is already in place. These SMEs will respond to increased demands in areas such as software and app development, digital marketing, cloud services 
Table 5. Contribution of Transport \& Logistics Sector in ASEAN

\begin{tabular}{|l|c|}
\hline & Transport \& Logistics Sector \\
\hline ASEAN GDP Size (US\$ Billions) & 140 \\
\hline ASEAN GDP (\% of Total) & $5 \%$ \\
\hline Employment (Millions) & 15 \\
\hline
\end{tabular}

Source: Bain \& Company Report in Hoppe, May \& Lin (2018)

and information security — domestically first and regionally thereafter — as ASEAN moves towards full digital integration.

ASEAN Community Progress Monitoring System 2017 noted a major achievement in ASEAN is enhanced connectivity through improvements in transport and other infrastructure networks which have brought the people and businesses closer than before. Tourism is a sector that has clearly benefited from better connectivity, while broadband access is key to thrive in a digital economy.

Referring to the ASEAN Sustainable Development Goals Indicators Baseline Report 2020, the number of fixed internet broadband subscriptions averaged 7.2 per 100 population in 2018. Singapore had the highest number at 26.4 per 100 population, followed by Viet Nam at 13.6, Brunei Darussalam at 10.0, and Malaysia at 8.2. Two ASEAN member states had numbers below the regional average, namely Philippines at 3.7 and Myanmar at 0.4 per 100 population with fixed broadband subscriptions.

No doubt, a digitally-enabled community is a hope for ASEAN to power and accelerate intraregional trade and growth through digital integration. As concluded in the study of Ahmedov (2020), the global economy and digitalization in international trade are growing rapidly and digital space is becoming a major area for global trade. The priority task of the development of the digital economy is to ensure fast economic growth, accelerate the integration in the international arena.

Therefore, ASEAN has much to gain by laying the foundation for the digital economy. Digital integration through a digitally-enabled community will be critical for ASEAN to compete at home and global. To strengthen ASEAN's opportunities to become global halal logistics, a digitally-enabled community also will accelerate the conduction of halal logistics more effectively, provide better organization of logistics as well as increase halal performance at all the supply chain.

\section{Towards A Global Halal Logistics}

As the fourth industrial revolution takes place, technological drivers transform lifestyles and industries. Referring to State of the Global Islamic Economy Report 2020/2021, with social distancing measures being applied across the world, digital connectivity is playing an important role in enabling crossborder e-commerce/m-commerce.

With 15 of the top 50 countries ranked according to smartphone penetration being Organization of Islamic Cooperation (OIC) countries, the demand for practical, digital Islamic economy solutions is gaining momentum, covering various sectors from Islamic finance and halal food to Islamic lifestyle products and services.

A fully digitally integrated transport and logistics sector will enable ASEAN to compete more effectively in the global value chain and boosting trade flows. The existence of four ASEAN member countries which are the top of the top 15 countries in GIEI is the lever. Moreover, as mentioned by Khairuddin \& Abdul Rahman (2020), if Malaysia is the country which exports the largest amount of halal products worldwide, Indonesia is the top Muslim consumer food expenditure market. Table 5 below shows the contribution of the transport and logistics sector to ASEAN by 2019. Its contribution is still 5\% of the ASEAN GDP. The existence of halal logistics which is supported by a digitallyenabled community is expected to boost the contribution of this sector to ASEAN GDP.

By connecting across all sizes and modes of logistics and connecting with customers and suppliers, digital integration within and across the entire supply chain will facilitate the seamless 
flows of goods. Referring to Hoppe, May \& Lin (2018), ASEAN logistics SMEs are still in the early stages of digital technology adoption. Only 35\% of surveyed logistics SMEs are aware of advanced tools like Enterprise Resource Planning (ERP) systems, and only 25\% use an ERP system in their operations today. The three most commonly cited barriers preventing logistics SMEs from adopting more advanced digital technologies are: (1) Uncertainty or lack of understanding of digital technology; (2) Affordability of technology such as high upfront investments required for systems; (3) After-sales service options which systems typically require an extended implementation timeline and ongoing support to ensure they are fit-for-purpose and updated.

As well as the barriers in logistics SMEs, according to Tieman \& Darun (2017), Arkeman (2020), Zaroni \& Musari (2020), digitizing the halal supply chain management, including the logistics in it also has problems: (1) Information system is still manual or semi-automatic and lack of integration of information technology systems; (2) The degree of automation and the degree of digitization is still low; (3) The absence of a good traceability (ability to verify the location of a product) system and organizing the product recalls with a smart and rapid halal test to check the product; (4) Transportation and warehousing downstream of the supply chain in accordance with halal requirements; (5) End-toend chain integrity (unbroken chain) from source to point of consumer purchase; (6) Different halal systems and interpretations of different markets.

Therefore, these problems require a radically different approach to how halal supply chains are orchestrated. There are two important things that need to be done: (1) Improve the traceability system with blockchain; (2) Improve blockchain intelligence through integration with smart and rapid halal tests. In other words, halal blockchains have the potential to solve all of the above halal supply chain problems. Likewise halal logistics, digitalization in this sector is a necessity. Absolutely, digitalization is needed by consumers who increasingly demand halal and ethical products. ASEAN as a digitalenabled community will strengthen the halal ecosystem to support ASEAN's global halal trade, both in the field of Halal Food, Islamic Finance, Muslim Friendly-Travel, Modest Fashion, Halal Media \& Recreation, and Halal Pharmaceutical \& Cosmetics. This is also opening up opportunities for ASEAN to become the leader of global halal logistics.

Although the halal industry is often seen as slow in responding to the latest innovations, Tan \& Junaida (2020), Noor (2020) wrote some countries in ASEAN have implemented digitalization, including a blockchain system, for halal industry. Some for the production process, logistics, up to the application for halal certification. In Singapore, in 2019, the WhatsHalal blockchain platform is available for companies wishing to apply for halal certification. In Malaysia, digital innovation has been adopted by the Department of Islamic Development, Malaysia (Jabatan Kemajuan Islam Malaysia/JAKIM) in halal auditing process. A good example of an innovative auditing tool that fulfils the aforementioned criteria is QuickHalal, a cloud-based mobile Halal auditing app that is developed by Holistics Lab Sdn Bhd, a spin-off company of Universiti Teknologi Malaysia. Until now, it has been used and tested by several multinational companies as well as Halal authorities, such as Halal Management Department and Jabatan Hal Ehwal Agama Islam Pulau Pinang (JHEAIPP).

Likewise leadership of Asia, leadership of ASEAN for global halal logistics is also carried out by Japan. In Indonesia, referring to Zaroni \& Musari (In Press), five of the eight logistics companies that provide halal services are companies from Japan. There are PT Nippon Express (NE), Indonesia, PT Nittsu Lemo Indonesia Logistik (NLIL), and PT Nex Logistics Indonesia (NEX LI) as the subsidiaries of Nippon Express, Co., Ltd. Nippon Express service ranks among the top five in the world with 737 locations. This company has begun working as a logistics provider since 1937.

There is also Yusen Logistics Co., Ltd. with a global network of more than 44 countries and regions. Like Nippon Express, Yusen Logistics is also developing logistics and transportation businesses in Southeast Asia by certifying the halal for its services. Before obtaining a halal certificate in Indonesia, a subsidiary of Yusen Logistics in Malaysia has obtained it first. In April 2015, Yusen Logistics became the first Japanese logistics provider to obtain halal certification in Malaysia for 
transportation and warehousing operations. In Thailand, in April 2017, Yusen Logistics also became the first Japanese logistics provider to obtain halal certification at a warehouse in Laem Chabang.

Then, a subsidiary of Kamigumi Co., Ltd. in Indonesia is PT Kamigumi Logistics Indonesia (KLI). On December 20, 2018, KLI also obtained halal certification from the Indonesian halal certification body. Kamigumi's international logistics network is currently comprising around 30 sites worldwide, with a focus on Asian locations where the growth is fierce, such as Singapore, Thailand and Vietnam.

In ASEAN, there is also one of the global brands of the Sejung Group from Korea. The Sejung Group currently has 22 branch offices in 8 countries with 200 partners around the world. To support halal logistics services under the CXL Halal brand, the Sejung Group has developed a subsidiary that runs a halal logistics transportation vehicle system called Sejung Shipping Co. Ltd. Halal logistics certification of Sejung Shipping Co. Ltd from the Korea Muslim Federation (KMF) which was later re-accredited with JAKIM certification. CXL Halal has also received halal certificates from the Ulama Council of Indonesia (MUI) and Majlis Ugama Islam Singapore (MUIS).

In Thailand, Kadir (2020) explained that manufacturers are now more aware of the increasing consumers' interest for the halal goods than before and there are opportunities for growth in the existing halal industry. Moreover, Thailand happened to be the world's first country owning the Halal Science Centre with the motive to be the number one halal hub. Even though a lot of adjustments and improvements would be required for the supply operation, in spite of that more logistics industrialists got involved in this market as the main core of the successful halal logistics management is the separation of halal products from that of non-halal. By participating in the halal industry, the participants/industrialists not only gain a lot of benefits but also enable themselves to create a sustainable halal ecosystem that contributes towards the halal economic growth.

Regarding the existence of halal blockchain to solve the problems within the halal supply chain, some ASEAN member states like Malaysia and Singapore have implemented a blockchain system for the halal industry. In Singapore, in 2019, the WhatsHalal blockchain platform is available for companies wishing to apply for halal certification.

According to Noor (2020), Malaysia has created a halal value chain with knowledge-based, capital-intensive powerhouses, and high technology, combining design and research and development activities. From halal product traceability to Islamic finance facilities, Malaysia can provide end-toend halal services. Slowly but sure, Hackius \& Petersen (2017) asserted the logistics and supply chain management community will realize how great blockchain could influence the industry.

Zaroni \& Musari (In Press, 2020) mentioned that blockchain will increase efficiency in the logistics sector because the process of exchanging data and records can be fast, easy, accurate, transparent, and safe. In halal logistics, this technology will help identify and trace the flow of documents in supply chain processes, including the halalness of processed products.

The big questions and also the research gaps that need to be answered and filled up are reflected by the 2 questions below:

1. Can ASEAN be the hub of global halal logistics?

2. Can a digitally-enabled community strengthen ASEAN's opportunities to become global halal logistics?

This study intends to fill the gaps by conducting a preliminary study through a correlation test to know how statistically significant the relationship between the existence of ASEAN digitally-enabled community and the opportunity for ASEAN to become a global halal logistics.

All data are collected from ASEAN Statistical Yearbook 2019 and ASEAN Secretariat since 2009 until 2019. Forecasting is carried out for 2020 and 2021 so that the total period of the study to be tested for the correlation is 13 years.

It is important to note that all variables used to measure digitally-enabled community and global halal logistics in this study are general variables for digitalization and logistics since there is a lack of 
study and available data related to the topic. Therefore, to the best knowledge of the authors, this is the first preliminary study in this regard which can be used as the foundation to conduct further studies.

\section{Correlation Test}

This study uses quantitative research method employing Pearson Correlation Test to derive inferences. The research questions that need to be answered by the correlation test is:

Is there a statistically significant relationship between ASEAN digitally-enabled community, as measured by internet subscribers/users per 100 persons and cellular/mobile phone per 100 persons, and the opportunity for ASEAN to become a global halal logistics, as measured by ASEAN GDP, ASEAN total air cargo, ASEAN total trade in goods, and ASEAN international air passenger traffic?

Referring to the type of all variable data, the correlation analysis uses Pearson Correlation. Pearson Correlation is the most widely used correlation statistic to measure the degree of the relationship between linearly related variables. Pearson Correlation assumes both variables should be normally distributed, linearity, and homoscedasticity. Then, based on the description, it can be constructed the following hypotheses:

$\mathbf{H}_{\mathbf{1}}$ : There is a statistically significant relationship between ASEAN digitally-enabled community, as measured by internet subscribers/users per 100 persons, and the opportunity for ASEAN to become a global halal logistics, as measured by ASEAN GDP.

$\mathbf{H}_{2}$ : There is a statistically significant relationship between ASEAN digitally-enabled community, as measured by internet subscribers/users per 100 persons, and the opportunity for ASEAN to become a global halal logistics, as measured by ASEAN total air cargo.

$\mathbf{H}_{3}$ : There is a statistically significant relationship between ASEAN digitally-enabled community, as measured by internet subscribers/users per 100 persons, and the opportunity for ASEAN to become a global halal logistics, as measured by ASEAN total trade in goods.

$\mathbf{H}_{4}$ : There is a statistically significant relationship between ASEAN digitally-enabled community, as measured by internet subscribers/users per 100 persons, and the opportunity for ASEAN to become a global halal logistics, as measured by ASEAN international air passenger traffic.

$\mathbf{H}_{5}$ : There is a statistically significant relationship between ASEAN digitally-enabled community, as measured by cellular/mobile phone per 100 persons, and the opportunity for ASEAN to become a global halal logistics, as measured by ASEAN GDP.

$\mathbf{H}_{\mathbf{6}}$ : There is a statistically significant relationship between ASEAN digitally-enabled community, as measured by cellular/mobile phone per 100 persons, and the opportunity for ASEAN to become a global halal logistics, as measured by ASEAN total air cargo.

$\mathbf{H}_{7}$ : There is a statistically significant relationship between ASEAN digitally-enabled community, as measured by cellular/mobile phone per 100 persons, and the opportunity for ASEAN to become a global halal logistics, as measured by ASEAN total trade in goods.

$\mathbf{H}_{8}$ : There is a statistically significant relationship between ASEAN digitally-enabled community, as measured by cellular/mobile phone per 100 persons, and the opportunity for ASEAN to become a global halal logistics, as measured by ASEAN international air passenger traffic.

Table 6 below shows the output of Pearson Correlation Test. The degree of association is measured by a Pearson Correlation Coefficient, denoted by $\mathrm{r}$. The Pearson Correlation Coefficient is measured on a scale that varies from +1 through 0 to -1 .

The correlation coefficient can range in value from -1 to +1 . The larger the absolute value of the coefficient, the stronger the relationship between the variables. For the Pearson Correlation, an absolute value of 1 indicates a perfect linear relationship. When one variable increases as the other increases the correlation is positive; when one decreases as the other increases it is negative. 
Table 6. Output of Pearson Correlation Test

\begin{tabular}{|c|c|c|c|c|c|c|}
\hline & & $\begin{array}{l}\text { Internet } \\
\text { Subscribers/ } \\
\text { Users per } 100 \\
\text { Persons }\end{array}$ & $\begin{array}{l}\text { GDP } \\
\text { (US\$ } \\
\text { Million) }\end{array}$ & $\begin{array}{l}\text { Total Air } \\
\text { Cargo } \\
\text { (Thousand } \\
\text { Ton) }\end{array}$ & $\begin{array}{l}\text { Total } \\
\text { Trade in } \\
\text { Goods (US\$ } \\
\text { Million) }\end{array}$ & $\begin{array}{l}\text { International Air } \\
\text { Passenger Traffic } \\
\text { (Thousand } \\
\text { Person) }\end{array}$ \\
\hline \multirow{3}{*}{$\begin{array}{l}\text { Internet } \\
\text { Subscribers/ } \\
\text { Users per } 100 \\
\text { Persons }\end{array}$} & $\begin{array}{l}\text { Pearson } \\
\text { Correlation }\end{array}$ & 1 & $.961 * *$ & $.972 * *$ & $.898^{* *}$ & $.994 * *$ \\
\hline & Sig. (2-tailed) & & .000 & .000 & .000 & .000 \\
\hline & $\mathrm{N}$ & 13 & 13 & 13 & 13 & 13 \\
\hline & & $\begin{array}{l}\text { Cellular/ } \\
\text { Mobile Phone } \\
\text { per } 100 \\
\text { Persons }\end{array}$ & $\begin{array}{l}\text { GDP } \\
\text { (US\$ } \\
\text { Million) }\end{array}$ & $\begin{array}{l}\text { Total Air } \\
\text { Cargo } \\
\text { (Thousand } \\
\text { Ton) }\end{array}$ & $\begin{array}{l}\text { Total Trade } \\
\text { in Goods } \\
\text { (US\$ } \\
\text { Million) }\end{array}$ & $\begin{array}{l}\text { International } \\
\text { Air Passenger } \\
\text { Traffic } \\
\text { (Thousand } \\
\text { Person) }\end{array}$ \\
\hline \multirow{3}{*}{$\begin{array}{l}\text { Cellular/Mobile } \\
\text { Phone per } 100 \\
\text { Persons }\end{array}$} & $\begin{array}{l}\text { Pearson } \\
\text { Correlation }\end{array}$ & 1 & $.872 * *$ & $.901 * *$ & $.760 * *$ & $.873 * *$ \\
\hline & Sig. (2-tailed) & & .000 & .000 & .003 & .000 \\
\hline & $\mathrm{N}$ & 13 & 13 & 13 & 13 & 13 \\
\hline
\end{tabular}

${ }^{*}$. Correlation is significant at the 0.01 level (2-tailed).

A correlation close to 0 indicates no linear relationship between the variables. Then, if the p-value is less than or equal to the significance level, the correlation is statistically significant. Otherwise, if the p-value is greater than the significance level, the correlation is not statistically significant.

Based on the output of Pearson Correlation Test, it indicates that the strength of association between internet subscribers/users per 100 persons and GDP, there is a very strong positive association $(r=0.961)$ and that the positive correlation coefficient is very highly significant because the $p$-value is less than the significance level. It indicates that high usage of internet in ASEAN can improve the GDP of ASEAN. It also means that there is a statistically significant relationship between ASEAN digitally-enabled community, as measured by internet subscribers/users per 100 persons, and the opportunity for ASEAN to become a global halal logistics, as measured by ASEAN GDP. In other words, $\mathrm{H} 1$ is accepted.

Then, between internet subscribers/users per 100 persons and Total Air Cargo is very highly and positively correlated $(r=0.972)$ and that the positive correlation coefficient is very highly significant because the p-value is less than the significance level. It indicates that that high usage of internet in ASEAN can boost the air cargo industry in ASEAN. It also means that there is a statistically significant relationship between ASEAN digitally-enabled community, as measured by internet subscribers/users per 100 persons, and the opportunity for ASEAN to become a global halal logistics, as measured by ASEAN total air cargo. In other words, $\mathrm{H} 2$ is accepted.

Then, between internet subscribers/users per 100 persons and total trade in goods, there is a very strong positive association $(r=0.898)$ and that the positive correlation coefficient is very highly significant because the p-value is less than the significance level. It indicates that that high usage of internet in ASEAN can boost the total trade in goods in ASEAN. It also means that there is a statistically significant relationship between ASEAN digitally-enabled community, as measured by internet subscribers/users per 100 persons, and the opportunity for ASEAN to become a global halal logistics, as measured by ASEAN international air passenger traffic. In other words, H3 is accepted.

Likewise, between internet subscribers/users per 100 persons and international air passenger traffic, there is also a very strong positive association $(\mathrm{r}=0.994)$ and that the positive correlation coefficient is very highly significant because the p-value is less than the significance level. It indicates that that high usage of internet in ASEAN can increase the air passenger traffic in ASEAN. 
It also means that there is a statistically significant relationship between ASEAN digitally-enabled community, as measured by internet subscribers/users per 100 persons, and the opportunity for ASEAN to become a global halal logistics, as measured by ASEAN international air passenger traffic. In other words, $\mathrm{H} 4$ is accepted.

Based on the output of Pearson Correlation test, it indicates that cellular/mobile phone per 100 persons and GDP has a very strong positive association $(\mathrm{r}=0.872)$ and that the correlation coefficient is very highly significant because the p-value is less than the significance level. It indicates that the high usage of cellular/mobile phone in ASEAN will increase the ASEAN's GDP. It also means that there is a statistically significant relationship between ASEAN digitally-enabled community, as measured by cellular/mobile phone per 100 persons, and the opportunity for ASEAN to become a global halal logistics, as measured by ASEAN GDP. In other words, H5 is accepted.

Then, between cellular/mobile phone per 100 persons and total air cargo is very highly and positively correlated $(r=0.901)$ and that the positive correlation coefficient is very highly significant because the p-value is less than the significance level. It indicates that the high usage of cellular/ mobile phone in ASEAN can improve the total air cargo in the South East Asian region. It also means that there is a statistically significant relationship between ASEAN digitally-enabled community, as measured by cellular/mobile phone per 100 persons, and the opportunity for ASEAN to become a global halal logistics, as measured by ASEAN total air cargo. In other words, H6 is accepted.

Then, between cellular/mobile phone per 100 persons and total trade in goods, there is a very strong positive association $(r=0.760)$ and that the positive correlation coefficient is very highly significant because the p-value is less than the significance level. It indicates that the high usage of cellular/mobile phone in ASEAN can boost the amount of total trade in goods in ASEAN. It also means that there is a statistically significant relationship between ASEAN digitally-enabled community, as measured by cellular/mobile phone per 100 persons, and the opportunity for ASEAN to become a global halal logistics, as measured by ASEAN total trade in goods. In other words, H7 is accepted.

Likewise, between cellular/mobile phone per 100 persons and international air passenger traffic, there is also a very strong positive association $(\mathrm{r}=0.873)$ and that the positive correlation coefficient is very highly significant because the p-value is less than the significance level. It indicates that the high usage of cellular/mobile phone in ASEAN can boost lift the internal air passenger traffic in ASEAN. It also means there is a statistically significant relationship between ASEAN digitallyenabled community, as measured by cellular/mobile phone per 100 persons, and the opportunity for ASEAN to become a global halal logistics, as measured by ASEAN international air passenger traffic. In other words, $\mathrm{H} 8$ is accepted.

Based on the above correlation test results, it is suggested that digitally-enabled community is very important to strengthen ASEAN's opportunities to become global halal logistics. There is a statistically significant positive relationship between ASEAN digitally-enabled community, as measured by internet subscribers/users per 100 persons and cellular/mobile phone per 100 persons, and the opportunity for ASEAN to become a global halal logistics, as measured by ASEAN GDP, ASEAN total air cargo, ASEAN total trade in goods, and ASEAN international air passenger traffic. Therefore, ASEAN countries aim to become the global halal logistics need to enhance digitalization in their country in order to achieve the vision. In other words, digitalization of halal logistics in the form of halal traceability and tracking system is the key for future development of halal industry in ASEAN. However, it is important to note that this correlation test is only a preliminary empirical study that confirms the relationship and yet further studies need to be conducted to strengthen the results of this study.

\section{CONCLUSION}

This study discusses ASEAN as the digitally-enabled community and how this can benefit ASEAN towards a global halal logistics. The significant contribution of this study is to initially evaluate 
ASEAN's opportunities to become global halal logistics through digitally-enabled community. Regarding the existence of ASEAN as a halal community and the commitment to developing the digital-enabled economy, this study did a correlation test to measure the strength of association and the direction of the relationship between ASEAN digitally-enabled community and chances for ASEAN becoming a global halal logistics. The correlation test shows that digitally-enabled community, as measured by internet subscribers/users per 100 persons and cellular/mobile phone per 100 persons, and the opportunity for ASEAN to become a global halal logistics, as measured by ASEAN GDP, ASEAN total air cargo, ASEAN total trade in goods, and ASEAN international air passenger traffic, are positively and statistically significant relationship. Therefore, halal authorities and other stakeholders should consider the results of this study as inputs for them in formulating policies to develop digitally-enabled halal community in their respective jurisdictions in order to achieve ASEAN's goal becoming the global halal logistics.

Despite the inferences, it is important to note that this study like other studies has some limitations. First, this study discusses the ASEAN as a regional block without taking into consideration the differences in each member country in terms of the variables used above. Second, this study only tests the correlation between the variables of digitally enabled community and logistic variables since it is considered as a preliminary study. Further studies can enhance this study by using regression analysis to evaluate the relationship between the variables. Third, the variables used to represent the halal logistics are general logistic variables and not specific for halal logistics since there are only limited previous studies that discuss the issue. Given the inferences and the limitation of the study, it can be concluded that digitalization in the form of halal traceability and tracking system is the key success factor of ASEAN to become the global hub of halal logistics. Therefore, government of ASEAN countries should focus on digitalization in order to achieve their global hub vision. 


\section{REFERENCES}

Abdullah, M. A., \& Azam, Md. S. E. (2020). Halal Industry in ASEAN: Issues and Challenges. In P. Ordoñez de Pablos, M. Almunawar, \& M. Abduh (Eds.), Economics, Business, and Islamic Finance in ASEAN Economics Community. Hershey, PA: IGI Global.

Ahmedov, I. (2020, July). The Impact Of Digital Economy On International Trade. European Journal of Business and Management Research, 5(4), 1-7. doi:10.24018/ejbmr.2020.5.4.389

Aravindan, A. (2020). Southeast Asia's Internet Economy to Hit $\$ 300$ Billion by 2025: Report. Retrieved from https://www.reuters.com/article/us-southeast-asia-internet-idUSKBN1WI07X

Arkeman, Y. (2020). Integrasi AI dan Blockchain untuk Agro-SCM Halal. A presentation material at Webinar 'Digitalisasi New Normal Industri Halal di Indonesia' held by Sucofindo.

ASEAN Secretariat, . (2017). ASEAN Statistical Report on Millennium Development Goals 2017. ASEAN Secretariat.

ASEAN Secretariat, . (2018). ASEAN Community Progress Monitoring System 2017. ASEAN Secretariat.

ASEAN Secretariat, . (2019). ASEAN Statistical Yearbook 2019. ASEAN Secretariat.

ASEAN Secretariat, . (2020). ASEAN Sustainable Development Goals Indicators Baseline Report 2020. ASEAN Secretariat.

Azam, M., \& Abdullah, M. A. (2020, March). Global Halal Industry: Realities and Opportunities. International Journal of Islamic Business Ethics, 5(1), 47-59. doi:10.30659/ijibe.5.1.47-59

Clarivate Report. (2020). Innovation in South and South East Asia. Retrieved from https://discover.clarivate. com/InnovationReportSASEA?utm_campaign=Innovation_Report_SASEA_Nurture_IPS_SEA_2020\&utm_ source $=$ trade_publication\&utm_medium $=$ affiliate

Dinar Standard, . (2020). State of the Global Islamic Economy Report 2020/2021. Dinar Standard, Dubai Islamic Economic Development Center, and Salam Gateway.

Hackius, N., \& Petersen, M. (2017). Blockchain in Logistics and Supply Chain: Trick or Treat? In W. Kersten, T. Blecker, \& C. M. Ringle, (Eds.), Digitalization in Supply Chain Management and Logistics: Smart and Digital Solutions for an Industry 4.0 Environment. Proceedings of the Hamburg International Conference of Logistics (HICL), No. 23. Berlin: epubli GmbH. doi:10.15480/882.1442

Hoppe, F., May, T., \& Lin, J. (2018). Advancing towards ASEAN Digital Integration Empowering SMEs to Build ASEAN's Digital Future. Report of Bain \& Company.

Kadir, S. A. (2020). The Development of Halal Logistics in Thailand. In N. A. A. Rahman, A. Hassan, \& M. F. Nizam (Eds.), Halal Logistics and Supply Chain Management in Southeast Asia (Islamic Business and Finance Series) (1st ed.). Routledge.

Kemp, S., \& Moey, S. (2019). Digital 2019: The Future of Ecommerce in Southeast Asia. Retrieved from https:// datareportal.com/reports/digital-2019-the-future-of-ecommerce-in-southeast-asia

Khairuddin, M. M., \& Abdul Rahman, N. A. (2020). Successful Halal Compliance Factors for Air Cargo Warehouse: Warehouse Operator Perspective. In N. A. Abdul Rahman, A. Hassan, \& M. F. Mohammad (Eds.), Halal Logistics and Supply Chain Management in Southeast Asia. New York: Routledge.

Noor, R. (2020). Percepatan Pembangunan Ekosistem Industri Halal di Indonesia melalui Intervensi Teknologi. A presentation material at Webinar 'Digitalisasi New Normal Industri Halal di Indonesia' held by Sucofindo.

OECD. (2019). Southeast Asia Going Digital: Connecting SMEs. Retrieved from www.oecd.org/going-digital/ southeast-asia-connecting-SMEs.pdf

Talib, M. S. A., Hamid, A. B. A., \& Zulfakar, M. H. (2015). Halal Supply Chain Critical Success Factors: A Literature Review. Journal of Islamic Marketing, 6(1), 44-71. Advance online publication. doi:10.1108/JIMA07-2013-0049 
Tan, M. I. I., \& Junaida, Z. (2020). Digital innovation, Halal industry and the Fourth Industrial Revolution. In N. A. Abdul Rahman, A. Hassan, \& M. F. Mohammad (Eds.), Halal Logistics and Supply Chain Management in Southeast Asia. New York: Routledge.

The ASEAN Post Team. (2019). Southeast Asia's Internet Economy Booming. Retrieved from https://theaseanpost. com/article/southeast-asias-internet-economy-booming

Tieman, M. (2011). The Application of Halal in Supply Chain Management: In-Depth Interviews. Journal of Islamic Marketing, 2(2), 186-195. doi:10.1108/17590831111139893

Tieman, M. (2013). Establishing the Principles in Halal Logistics. Journal of Emerging Economies and Islamic Research, 1(1), 1-13. doi:10.24191/jeeir.v1i1.9115

Tieman, M., \& Darun, M. R. (2017). Leveraging Blockchain Technology for Halal Supply Chains. Islam and Civilisational Renewal, 8(4), 547-550. doi:10.12816/0045700

Tieman, M., \& Ghazali, M. C. (2014). Halal Control Activities and Assurance Activities in Halal Food Logistics. Social and Behavioral Sciences, 121, 44-57. doi:10.1016/j.sbspro.2014.01.1107

Tieman, M., van der Vorst, J. G. A. J., \& Ghazali, M. C. (2012). Principles in Halal Supply Chain Management. Journal of Islamic Marketing, 3(3), 217-243. doi:10.1108/17590831211259727

USAID. (2020). Growing ASEAN's Digital Economy. ASEAN-USAID Ignite: Digital Economy, 1-2. Retrieved from https://asean.usmission.gov/wp-content/uploads/sites/77/IGNITE-Digital-Economy-fact-sheet-Aug2020.pdf

Zailani, S., Iranmanesh, M., Aziz, A. A., \& Kanapathy, K. (2017). Halal Logistics Opportunities and Challenges. Journal of Islamic Marketing, 8(1), 127-139. doi:10.1108/JIMA-04-2015-0028

Zaroni \& Musari, K. (In Press). Logistik Halal: Memahami Ekosistem, Operasional, dan Praktik Terbaik. Jakarta: Prasetiya Mulia Publishing.

Zaroni \& Musari, K. (2020). Blockchain, Digitalisasi Logistik menuju Halal Global. TruckMagz, 75(6), 42-45.

Sutan Emir Hidayat is the Director of Islamic Economy Supporting Ecosystem at the National Committee for Islamic Economy and Finance (KNEKS), Indonesia. He obtained his PhD and MBA degrees in Islamic Finance from International Islamic University Malaysia. He is currently also a permanent academic staff at Gunadarma University, Indonesia. He was an Associate Professor and Head of Business School at University College of Bahrain. He has published a significant number of research papers in reputable international journals as well as several books and contributed chapters in many books. He was recognized as one of the top influential 500 personalities on a global scale by ISFIN, a leading advisory firm for Islamic markets.

Khairunnisa Musari is currently an Assistant Professor at Department of Islamic Economics, Postgraduate Program and Faculty of Islamic Business Economics (FEBI), Kiai Haji Achmad Shiddiq State Islamic University (UIN KHAS), Jember, Indonesia. She is a member of the Indonesian Association of Islamic Economist (IAEI) and a Lead Independent Associate Ambassadors of VentureEthica. She has experience as a Senior Specialist for Islamic Finance of UNDP Indonesia. She was listed as the Top 150 Most Influential Women in Islamic Business \& Finance 2020 by Cambridge-IFA. 